crowded. Now great masses of people can concentrate in towns secure in the promise of food, shelter and clothing. In 1936 the population of London is as great as that of all England a hundred years ago. The materials required for human life in crowded centres are obtained by the steam engine. Science and engineering accelerated the growth of the 'empire of the machine'. Men everywhere, although freed from the soil, feel themselves enslaved to the machine. To-day, four of the largest modern turbines have an energy capacity greater than that of the entire adult working population of the United States.

Mankind now appears to be on the eve of a third industrial revolution. We have machines watched and directed by other machines. As an example, consider the photo-electric cell, which never makes a mistake and never knows fatigue. It is used for many and varied purposes. It sorts vegetables, fruit and eggs, it measures illumination, appraises colours, classifies minerals, counts bills and throws out counterfeits. It times races, counts people and vehicles, records smoke in tunnels, directs traffic automatically and substitutes a new process for photo-engraving. Automatically controlled machinery for making lamp bulbs at Corning, New York, produces 650 thousand bulbs per machine per day, which is ten thousand times more than that produced by the methods previously employed. Remarkable progress in material culture has been witnessed during the last hundred years; but institutions, social customs and thought patterns have, as always, lagged behind. Saint Pièrre's idea of progress is beginning to be challenged; some social pessimists are substituting the notion of change for that of progress. To establish control over the gigantic material gains and to cope with the resultant problems are the challenges facing mankind to-day. Many years may be required to solve them, but surely that intelligence which has performed such marvellous feats in material matters will find an avenue for social progress.

\section{The Newcomen Society}

AT a meeting of the Newcomen Society held at the Iron and Steel Institute on November 18, the report of the Council for the session 1935-36 was presented. This showed that the activities of the Society have been well maintained and that the total membership is now 424 as compared with 343 a year ago. There has been a considerable increase in the membership in America. Fourteen papers were read during the session and the Society has published as an extra publication the "Collected Papers" of Mr. Rhys Jenkins, one of the founders of the Society. Mr. W. J. Tennant was elected president for the ensuing year. After the passing of the report and accounts, a paper was read by Dr. J. Thomas on "Josiah Wedgwood as a Pioneer of Steam Power in the Pottery Industry". By searching the Boulton and Watt papers at the Public Library and the Assay Office at Birmingham, Dr. Thomas has brought to light new material relating to the introduction of the Watt rotative steam engine into industry in the Midlands, and he has come to the conclusion that the earliest of such engines installed in a factory was that supplied to Wedgwood and erected at Etruria in 1782. Wedgwood's faith in the steam engine was shown by the financial assistance he gave to Boulton at a critical time. Like Priestley, Erasmus Darwin, Keir, Boulton, Watt and others, Wedgwood was a member of the famous Lunar Society, and his scientific leanings were shown in many ways. Towards the close of his paper, Dr. Thomas was able to show by a series of lantern slides how Watt used the medallions and casts of Wedgwood when in his retirement he devoted his time to the construction of the two statuary reproducing machines now preserved in Watt's garret workshop at the Science Museum. There can be little doubt that Watt's work in this direction was largely due to his friendship with Wedgwood.

\section{New Tube Trains in London}

EXPERIMENTs have recently been made on the first of four six-car tube trains manufactured by the Metropolitan-Cammell Carriage and Wagon Co., Ltd. for the London Passenger Transport Board. The train is composed of three two-car units, each car having the whole of the electric equipment under the floor. This avoids the necessity of a switch compartment, and so the new six-car train has approximately the same sitting accommodation as the existing seven-car train. The acceleration has been increased to two miles per hour per second and the braking rate (deceleration) to three miles per hour per second. The increased power has been gained partly by driving directly fifty per cent of the axles and by arranging so that more of the weight of the train is available for cohesion. The total horse-power of the new trains will be 1,650, as compared with 960 for the existing six-car trains. Several firms have suggested various schemes for operating the trains, but the following features are common to them all. All the control is operated at 50 volts and each car is separate and complete. Resistance switches are never called upon to brake under load. Each of the bogies is of all-welded construction and each carries one traction motor on the inside axle. This arrangement provides 58 per cent of the available weight of the car for adhesion. Three of the trains are streamlined at the driving end. The driver's seat is in the centre of the cab, with the master controller and braking controller on either side. The air-operated sliding doors are electrically controlled. Particulars with photographs are given in the Electrical Review of November 20.

\section{Steamship Communication between Europe and America}

In the Metropolitan Vickers Gazette of October, Mr. Leivesley continues his papers on notable ships and their equipment. He points out that it is now ninetysix years since a regular steamship communication was inaugurated between Europe and America. This was first established by the Cunard S.S. Britannia in July 1840, which crossed from Liverpool to Boston 